\title{
INVESTIGATION OF EFFECTS OF MIG WELDING ON CORROSION BEHAVIOUR OF AISI 1010 CARBON STEEL
}

\author{
Nur Azhani Abd Razak ${ }^{1 *}$ and Shing Shian $\mathrm{Ng}^{1}$ \\ ${ }^{1}$ Faculty of Mechanical Engineering, Universiti Malaysia Pahang, \\ 26600 Pekan, Pahang, Malaysia \\ *Email: azhani@ump.edu.my \\ Phone: +6094246273; Fax: +609424622
}

\begin{abstract}
This paper presents the corrosion behaviour of welded low carbon steel at different welding voltages and filler materials. The welding process was conducted on butt joint specimens using the metal inert gas (MIG) technique at a welding voltage range of 19 to $21 \mathrm{~V}$ with $1 \mathrm{~V}$ interval, and the filler materials used were ER 308L and ER 70S-6 with $1.2 \mathrm{~mm}$ diameter. Heat treatment through full annealing was done to the welded low carbon steel, and the corrosion behaviour was tested using a synthetic seawater environment with $3.5 \mathrm{wt} \% \mathrm{NaCl}$. Microstructure changes were observed using a scanning electron microscope (SEM). The results showed that the corrosion rate decreased when the welding voltage increased, as it directly affected the welding heat input. The welding heat input was found to have a significant effect on the corrosion rate as it changed the ferrite content in the microstructure of the specimens. Decrease in the corrosion rate was also found when the full annealing process was done to the specimens and ER 308L filler material was used. From a metallographic study, iron oxides and pitting were found on the surface of the exposed area after the corrosion test. It is apparent that the combination of higher welding voltage, heat treatment and the use of ER 308L filler material can reduce the corrosion rate of AISI 1010 carbon steel.
\end{abstract}

Keywords: Filler material; corrosion behaviour; low carbon steel; welding voltage; full annealing.

\section{INTRODUCTION}

Carbon steel is the most widely used engineering material despite its relatively limited corrosion resistance. It is used in large tonnages in marine applications, nuclear power and fossil fuel power plants, transportation, chemical processing, petroleum production and refining, pipelines, mining, construction and metal-processing equipment. Carbon steel has been the popular choice of structural material as it is abundantly available, inexpensive and has adequate mechanical properties, but it has a high general corrosion rate [1-4].

Most of the structures, especially in marine applications, are fabricated by the technique of welding. Welding is a reliable and efficient metal-joining process which is widely used in industry. However, during the welding process, due to the different quantities of heat input as well as the quality of the weldments, many problems arise from the process, especially in corrosion $[5,6]$. The cycle of heating and cooling that occurs during the welding process affects the microstructure and surface composition of the welds and adjacent base metal. The metallurgical factor is one of the primary 
concerns with the corrosion of welded carbon steel [7]. When a welded structure is exposed to water containing corrosion-aggressive ions such as chloride ions, corrosion becomes severe, even in a short period of exposure [8, 9]. In such a condition, localized corrosion such as galvanic corrosion or intergranular corrosion, coupled with a reduction reaction of dissolved oxygen, can occur because the welded structure is composed of different metals or has heterogeneity in the heat-affected zone (HAZ) induced by the welding process [9-12]. Furthermore, these weldments are usually more vulnerable to stress corrosion cracking than the corresponding base plates, while the welded zones represent potential weak links which may limit or impair performance [13-15]. Thus, improvements in weldment properties are critical to increase the reliability of high-performance structures utilizing welded carbon materials.

Several studies have been done to investigate the effect of welding parameters on the corrosion behaviour of various metals. Rajakumar, Muralidhara [16] reported that all welding parameters have a significant effect on the corrosion rate of AA6061-T6 aluminium alloy. He mentioned that the corrosion rate was at its maximum when the tool rotational speed was at lower and higher levels, whereas the corrosion rate was found to be the minimum when the welding speed was at $80 \mathrm{~mm} / \mathrm{min}$ [16]. Yousefieh, Shamanian [17], while investigating the optimization of the pulsed current gas tungsten arc welding (PCGTAW) parameters for corrosion resistance, found that the percentages of pulse current, background current, $\%$ on time and pulse frequency on the corrosion resistance were $66.28 \%, 25.97 \%, 2.71 \%$ and $5.04 \%$ respectively [17]. Another study done by Fahimpour, Sadrnezhaad [18] in 2012 mentioned that friction stir welding results in joints having higher resistance to corrosion as compared to gas tungsten arc welding, and T6 heat treatment improved the corrosion resistance of welds [18]. Although a number of investigations and studies have been conducted, to the best of the authors' knowledge and according to the literature study, work on the effects of welding parameters and combined with the heat treatment process on the corrosion behaviour of AISI 1010 is still lacking. Thus, this research work concentrates purely on the corrosion behaviour of AISI 1010 carbon steel. The present paper emphasizes the effects of different metal inert gas (MIG) welding parameters, namely welding voltage and filler material, and in combination with the heat treatment process, on the corrosion behaviour of AISI 1010 carbon steel.

\section{EXPERIMENTAL PROCEDURE}

\section{Materials}

In this study, the material used was AISI 1010 carbon steel $40 \mathrm{~mm}$ in length, $25 \mathrm{~mm}$ wide and $3 \mathrm{~mm}$ thick. The chemical composition, obtained by emission spectroscopy, is given in Table 1.

\section{Heat Treatment Process}

Twelve plates of AISI 1010 carbon steel were used in this study in as-received condition, while another 12 plates were subjected to the heat treatment process of full annealing. The plates were heated in a furnace at $950{ }^{\circ} \mathrm{C}$ and held for 2 hours. Then they were set to cool in the furnace as it was switched off so that their temperature decreased at the same rate as that of the furnace. 
Table 1. Chemical composition of the as-received carbon steel.

\begin{tabular}{ccccccc}
\hline \multirow{2}{*}{ Material } & \multicolumn{6}{c}{ Chemical Composition, weight \% } \\
\cline { 2 - 7 } & $\mathrm{Fe}$ & $\mathrm{C}$ & $\mathrm{Mn}$ & $\mathrm{P}$ & $\mathrm{S}$ & $\mathrm{Si}$ \\
\hline AISI 1010 Carbon Steel & 99.647 & 0.10 & 0.223 & 0.01 & 0.01 & 0.01 \\
\hline
\end{tabular}

\section{Welding Process}

The MIG welding technique was employed to join the plates together. The butt joint process was performed with two different filler materials, ER 308L and ER 70S-6. ER 308L stainless steel solid wire has low carbon content which helps to prevent intergranular corrosion, whereas ER 70S-6 is a premium mild steel solid wire which provides high quality welds. The major chemical composition of both filler materials is shown in Table 2.

Table 2. Chemical composition for the filler materials.

\begin{tabular}{ccccccc}
\hline Type of & \multicolumn{6}{c}{ Chemical Composition, weight \% } \\
\cline { 2 - 7 } Filler & $\mathrm{C}$ & $\mathrm{Mn}$ & $\mathrm{P}$ & $\mathrm{Si}$ & $\mathrm{Cu}$ & $\mathrm{Cr}$ \\
\hline ER 308L & 0.03 & $1.00-2.50$ & 0.03 & $0.30-0.65$ & 0.75 & $19.5-22.0$ \\
ER 70S-6 & $0.06-0.15$ & $1.40-1.85$ & 0.25 & $0.80-1.15$ & 0.50 & 0.15 \\
\hline
\end{tabular}

All the necessary care was taken to avoid joint distortion, and the joints were made after securing the plates with suitable clamps. Prior to welding, the base metals were cleaned using ultrasonic cleaning apparatus. Three different welding voltages were used during the MIG welding process, namely $19 \mathrm{~V}, 20 \mathrm{~V}$, and $21 \mathrm{~V}$. The base current and the welding speed were set to be constant. The wire feed rate was set to be 100 inch per minute as the welding process was done. The welded specimen is shown in Figure 1.

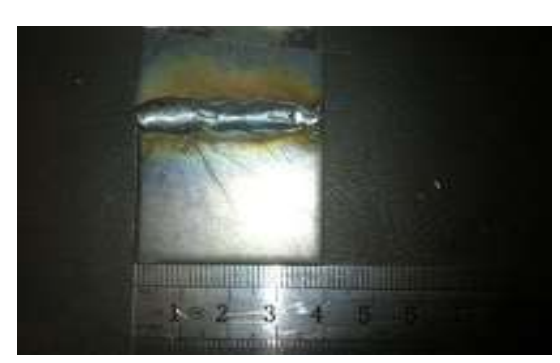

Figure 1. Welded specimen.

\section{Structural Characterization}

Surface preparations of the samples were prepared by standard metallographic techniques which consist of wet grinding with various abrasive papers, mechanical polishing by using a diamond compound, and then etching with the right etchant, depending on the type of filler material used. For the ER 70S-6 filler material, the etchant used was $2 \%$ nital for both base metal and welded joint. However, a mixture of hydrochloric acid, glycerol and nitric acid was used to etch the welded joint for ER 308L filler material, with $2 \%$ nital for the base metal. Then, the specimens were 
cleaned with distilled water and ethanol to prevent corrosion on the surface of the specimens. An optical microscope was used to study the microstructure and morphology of the specimens after the welding process.

\section{Electrochemical Testing}

A WonATech model WPG100 potentiostat and IVMan 1.2 software were used for monitoring the corrosion potentials of the specimens as well as potentiodynamic polarization measurements. The photograph of the potentiodynamic polarization set-up is shown in Figure 2.

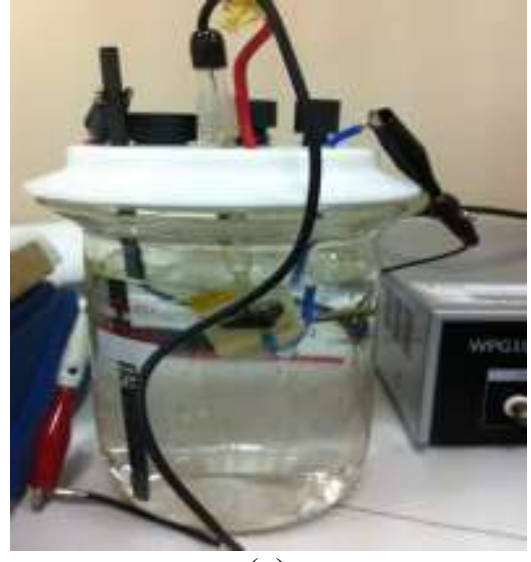

(a)

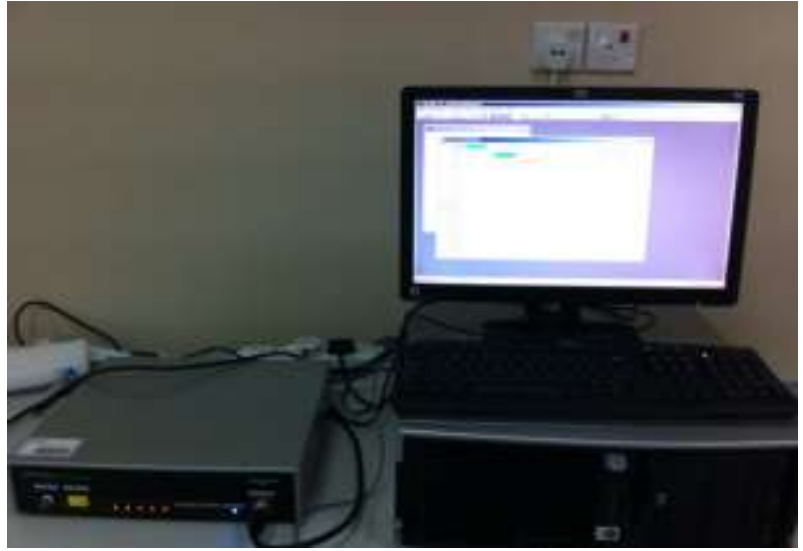

(b)

Figure 2. Potentiodynamic polarization set-up: (a) electrochemical measurement set-up; (b) WPG100 potentiostat.

The experimental set-up for the electrochemical measurements consisted of a three-electrode cell with the sample as a working electrode with an exposed area 0.6 $\mathrm{cm}^{2}$, a saturated calomel electrode (SCE) as a reference electrode and a graphite rod as the counter electrode. The working electrode, shown in Figure 3, was placed in a cell consisting of synthetic seawater solution with $3.5 \mathrm{wt} \% \mathrm{NaCl}$. Measurements of the polarization curves were recorded in the potential range of -1200 to $0 \mathrm{mV}$ and at a scan rate of $20 \mathrm{mV} \mathrm{s}^{-1}$. The anodic and cathodic polarization curves were obtained for each specimen and the corrosion potentials and corrosion current densities were determined by the Tafel extrapolation and linear polarization methods.

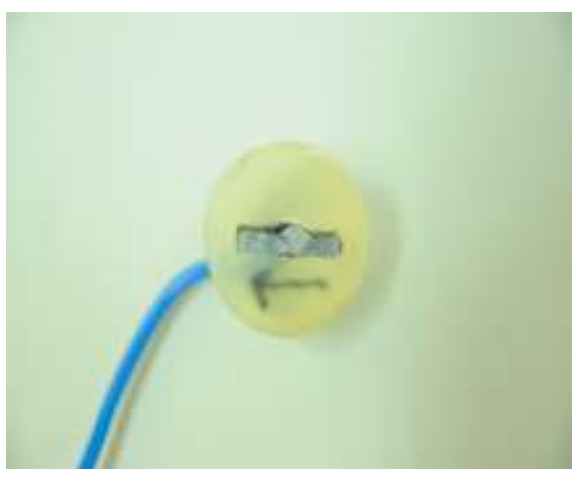

Figure 3. Working electrode consisting of weld metal and base metal. 


\section{RESULTS AND DISCUSSION}

\section{Microstructural Examination of AISI 1010 Carbon Steel}

From the observation of the microstructures under an optical microscope (Figure 4) for the base metal of (a) non-heat-treated and (b) heat-treated AISI 1010 carbon steel, ferrite (B), pearlite (A) and the grain boundary cementite film (GB) were found in the microstructure. By comparison, the amount of pearlite, ferrite and the grain boundary cementite film (GB) differed between the non-heat-treated and heat-treated AISI 1010 carbon steel. The grain sizes for the heat-treated AISI 1010 carbon steel are much more variable, and found to be larger than the non-heat-treated AISI 1010 carbon steel. The specimens were heated at $950^{\circ} \mathrm{C}$ for two hours and thus had transformed all the ferrite content into austenite form. Under this heating process, the specimens were homogenized. The AISI 1010 carbon steel was then cooled in-situ to achieve a slow cooling rate. This results in a coarse pearlite structure. According to Smith and Hashemi [19], fully annealed steel is soft and ductile with no internal stress.

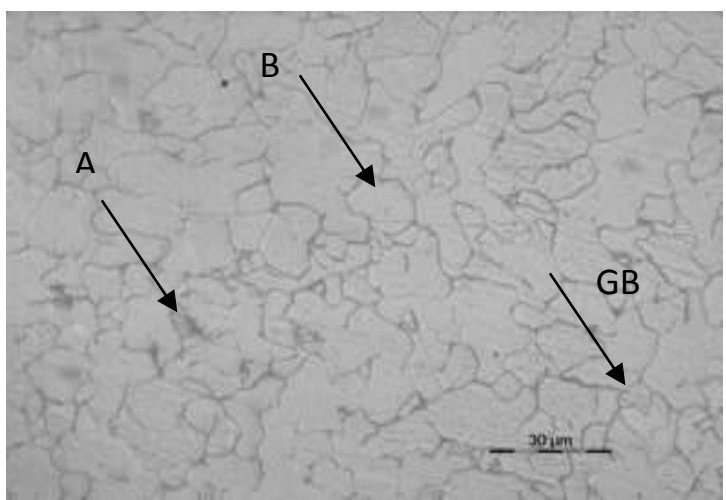

(a)

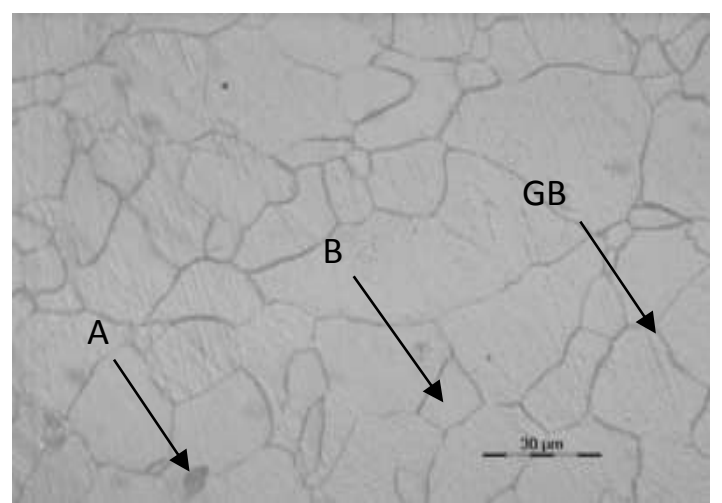

(b)

Figure 4. Microstructures of the base metal (a) non-heat-treated, (b) heat-treated.

The microstructures of the welded joint (weldment) for specimens with welding voltages of $19 \mathrm{~V}$ and $21 \mathrm{~V}$ and welding filler ER 70S-6 were compared in order to study the differences in microstructure content. The microstructure of the weldment was labelled with PF (polygonal ferrite), FS (aligned side plate ferrite, also known as Widmanstatten ferrite) and AF (acicular ferrite). It was found by observing the images in Figure 5 that weldments without the heat-treatment process at welding voltages of 19 $\mathrm{V}$ and $21 \mathrm{~V}$ with ER 70S-6 filler material had different amounts of acicular ferrite, polygonal ferrite and the aligned side plate ferrite. By comparing the two figures, the amount of acicular ferrite with a welding voltage of $19 \mathrm{~V}$ was lower than in the weldment which was welded at a voltage of $21 \mathrm{~V}$. The polygonal ferrite, which looked similar to ferrite, inhabits much of the weldment zone in the specimen with a welding voltage of $19 \mathrm{~V}$. For specimens with a welding voltage of $21 \mathrm{~V}$, the aligned side plate ferrite/Widmanstatten ferrite and the acicular ferrite inhabit much of the weldment microstructure [20]. The acicular ferrite found in the microstructure of the weldment is actually a microstructure of ferrite which is characterized by needle-shaped crystallites. These grains are actually a thin lenticular shape. This acicular ferrite is of benefit to the microstructure as it can increase the toughness of the specimen due to its chaotic 
ordering. The acicular ferrite microstructure is more advantageous than other microstructures [21].

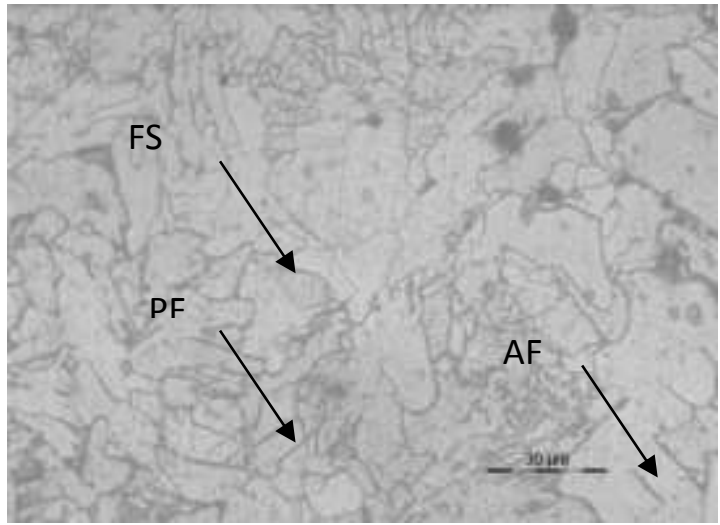

(a)

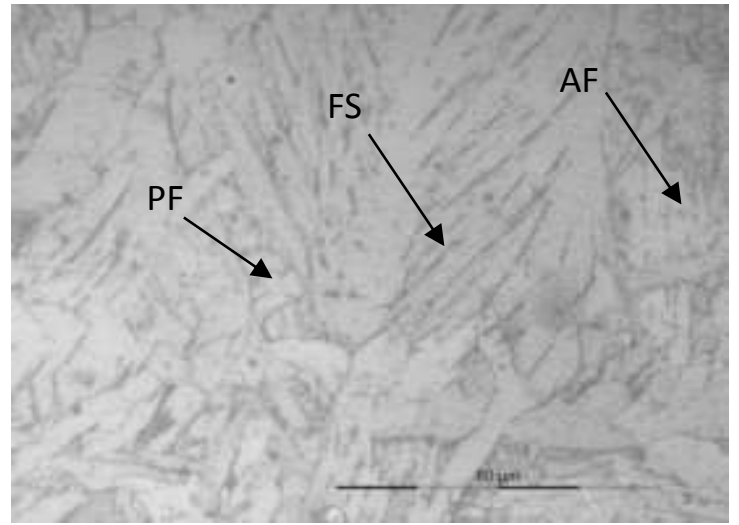

(b)

Figure 5. Microstructure of weldment for non-heat-treated specimens welded with ER 70S filler: (a) $19 \mathrm{~V}$; (b) $21 \mathrm{~V}$.

Aligned side plate ferrite or Widmanstatten ferrite in the microstructure of the weldment increases as the austenite grain size and the cooling rate of the weldment increase. By decreasing the austenite grain size and increasing the cooling rate, both yield strength and impact toughness will increase [22]. The overall refinement of Widmanstatten ferrite contributes strength and toughness to the microstructure. Polygonal ferrite nucleates at the austenite grain boundaries and in intragranular regions. Polygonal ferrite is transformed at high temperatures and is favoured in high heat input processes. A large amount of polygonal ferrite is not considered beneficial to toughness, especially in higher strength steels. It is of lower strength than other transformation products.

\section{Polarization Results of Electrochemical Test}

Polarization diagrams for the 12 specimens were generated with the WonaTech WPG100 potentiostat and are shown in Figures 6 and 7. Tafel analysis was performed by extrapolating the linear portions of the logarithm of absolute current density and the corrosion potential plot. The corrosion behaviour of the specimens was determined by Tafel analysis on the polarization diagrams. The corrosion rates of the specimens at different welding parameters are shown in Table 3, while the trend of the corrosion rate at various welding voltages is illustrated in Figure 8. Based on the graph for both heattreated and non-heat-treated AISI 1010 carbon steel in Figure 8, the corrosion rate of the specimens decreases as the welding voltage increases. The non-heat-treated AISI 1010 carbon steel has a higher corrosion rate than the heat-treated AISI 1010 carbon steel because the latter was subjected to the full annealing process. Thus, it can be said that the specimens that underwent the heat-treatment process display better corrosion resistance than the non-heat-treated specimens. Moreover, specimens welded with ER 308L filler have a lower corrosion rate than welded specimens with ER 70S-6 filler material. The chemical composition of the ER 70S-6 and ER 308L fillers was shown in Table 2. ER 308L filler has a lower carbon content and higher chromium content than ER 70S-6 filler. The high chromium content in the ER 308L filler makes it more 
resistant to rust than other types of steel. The chromium combines with oxygen in the atmosphere to form a thin invisible layer that is normally known as passive film. If the materials are cut or scratched and the passive film is disrupted, more oxide will quickly form and recover the exposed surface, protecting it from oxidative corrosion.

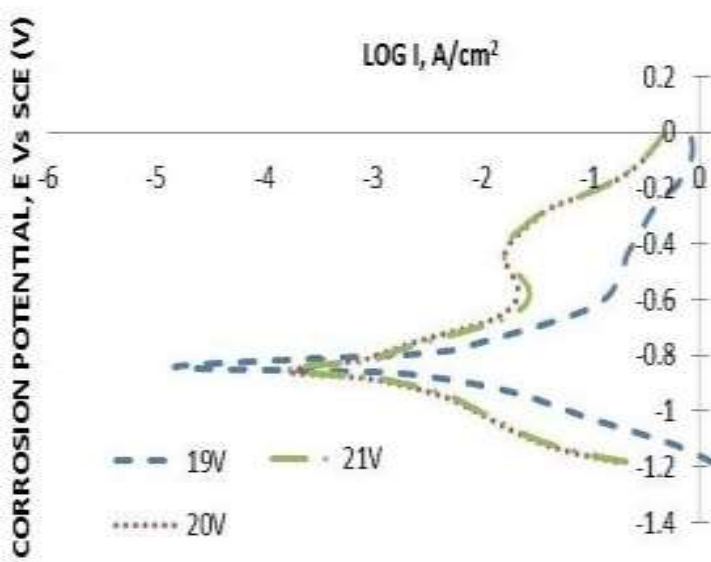

(a)

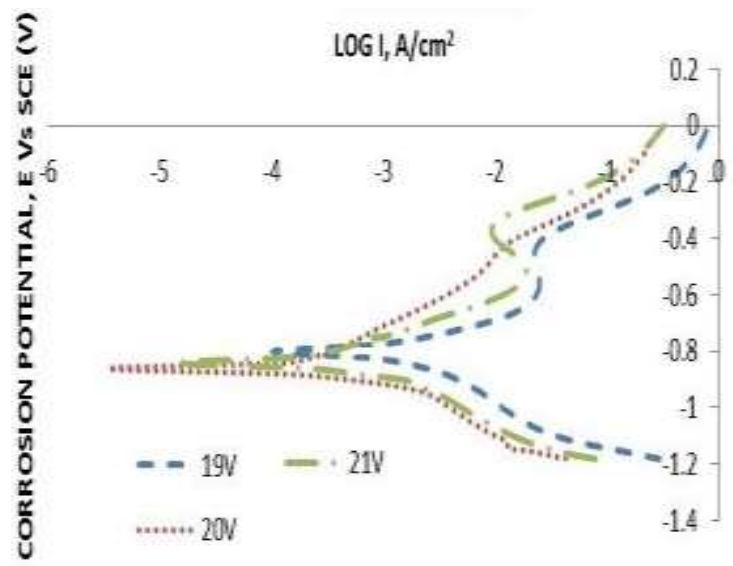

(b)

Figure 6. Polarization diagram for welded AISI 1010 carbon steel with ER 70S-6 filler: (a) non-heated; (b) heat-treated.

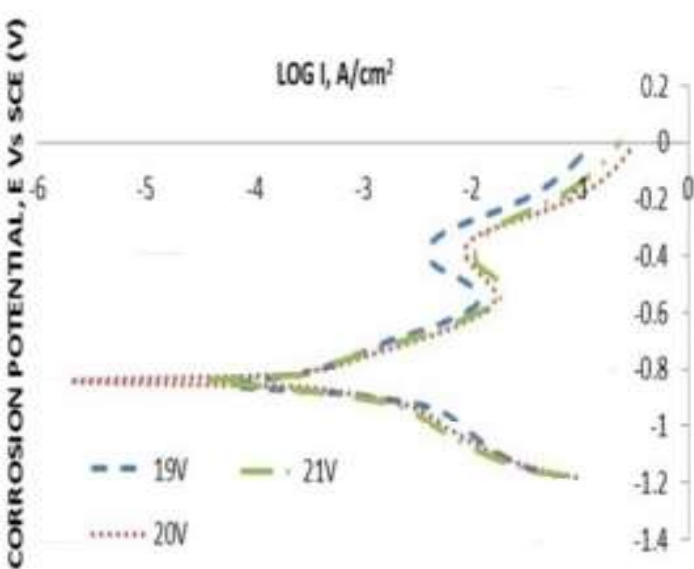

(a)

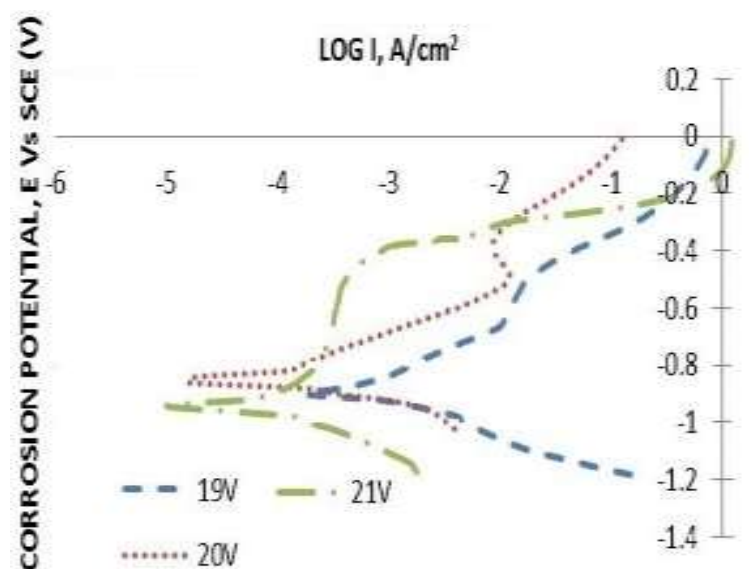

(b)

Figure 7. Polarization diagram for welded AISI 1010 carbon steel with ER 308L filler: (a) non-heated, (b) heat-treated.

As the welding voltage increases, the welding heat input will increase and indirectly increases the welding temperature. The welding temperature will affect the microstructure changes in the weldment. These microstructure changes were shown in Figure 5. The difference in welding voltage will result in different microstructures at the weldment. By comparing the images in Figure 5, the weldment with a welding voltage of $21 \mathrm{~V}$ has more polygonal ferrite which is considered not to be beneficial to the toughness of the specimen. The weldment with a welding voltage of $21 \mathrm{~V}$ has a large amount of acicular ferrite and aligned side plate ferrite, which contribute to the strength and toughness of the welded AISI 1010 carbon steel. The weldment of the specimen with a welding voltage of $21 \mathrm{~V}$ has better mechanical properties due to the ferrite 
content in the microstructure. In other words, a higher welding heat input will result in a lower corrosion rate for the welded AISI 1010 carbon steel.

Table 3. Corrosion rate of specimens at different welding parameters.

\begin{tabular}{|c|c|c|c|c|}
\hline \multirow{3}{*}{$\begin{array}{c}\text { Welding } \\
\text { Voltage, V }\end{array}$} & \multicolumn{4}{|c|}{ Corrosion Rate, mmpy } \\
\hline & \multicolumn{2}{|c|}{ Non-heat treated } & \multicolumn{2}{|c|}{ Heat treated } \\
\hline & $\begin{array}{l}\text { ER 70S-6 } \\
\text { (mild steel } \\
\text { filler) }\end{array}$ & $\begin{array}{c}\text { ER 308L } \\
\text { (stainless steel } \\
\text { filler) }\end{array}$ & $\begin{array}{c}\text { ER 70S-6 } \\
\text { (mild steel } \\
\text { filler) }\end{array}$ & $\begin{array}{c}\text { ER 308L } \\
\text { (stainless stee } \\
\text { filler) }\end{array}$ \\
\hline 19 & 28.4 & 14.9 & 19.1 & 10.8 \\
\hline 20 & 20.5 & 8.3 & 11.7 & 6.1 \\
\hline 21 & 15.2 & 4.3 & 6.8 & 1.2 \\
\hline
\end{tabular}

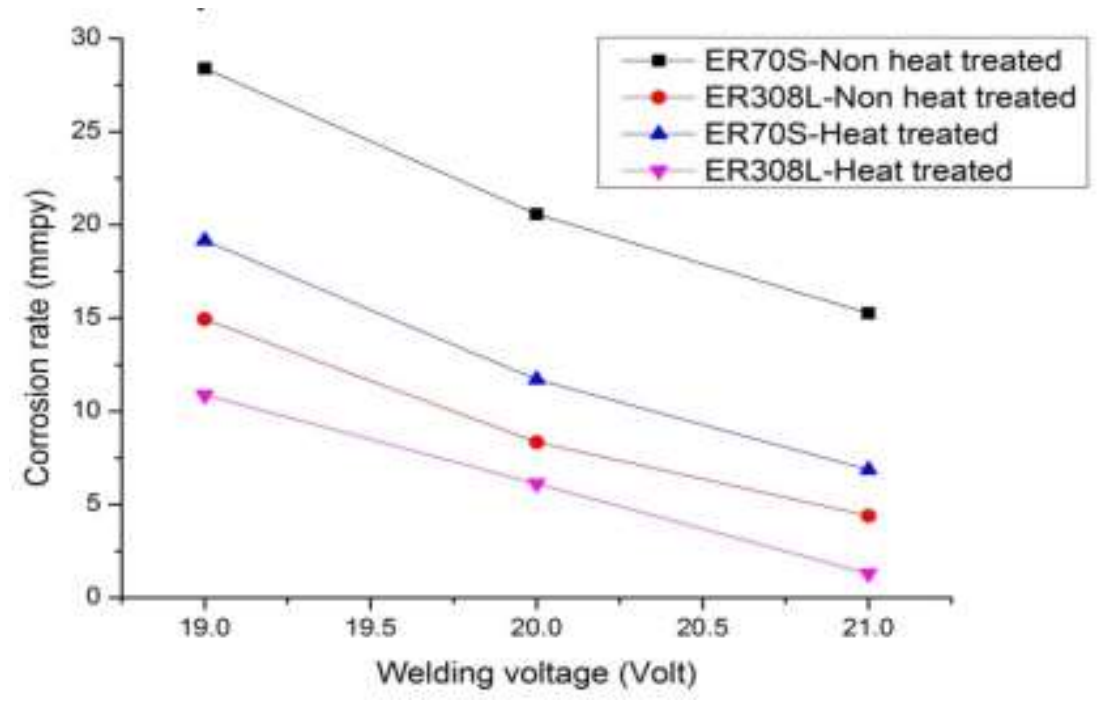

Figure 8. Corrosion rate at different welding voltages for welded AISI 1010 carbon steel.

\section{Scanning Electron Microscopy Result}

The SEM image in Figure 9 shows the morphology of the specimen without undergoing the cleaning process after the immersion test. Corrosion exists due to the exposed surface area after electrochemical testing. Coral-like shapes were found in the SEM image. The corrosion products formed on the surface of the specimen were iron oxides, generally termed rust [23]. These iron oxides consist of iron (III) oxides and iron (III) oxide-hydroxide. The SEM image of the specimen that underwent the cleaning process after electrochemical testing is shown in Figure 10. Based on the image, a pitting defect was found on the surface of the specimen. In welding, pits are usually found at specific microstructural features in the weld deposit $[24,25]$. Pitting is a form of extremely localized attack that results in holes in the metal. These holes may be small or large in diameter, but in most cases they are relatively small. It is difficult to detect pits because of their small size and pits are often covered with corrosion products. 


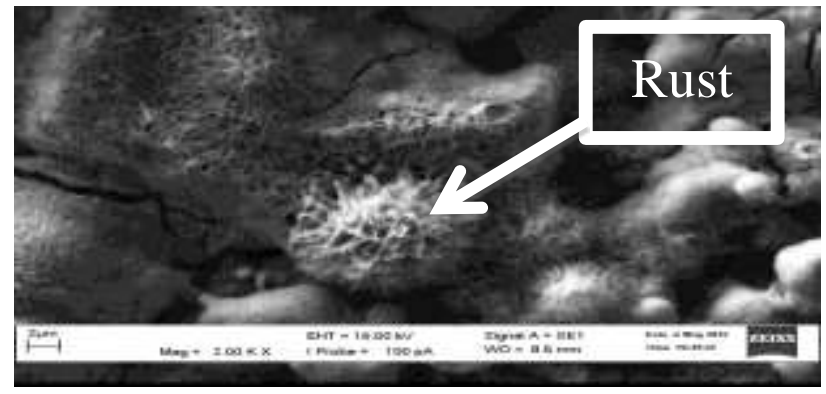

Figure 9. Corrosion product formed after electrochemical test.

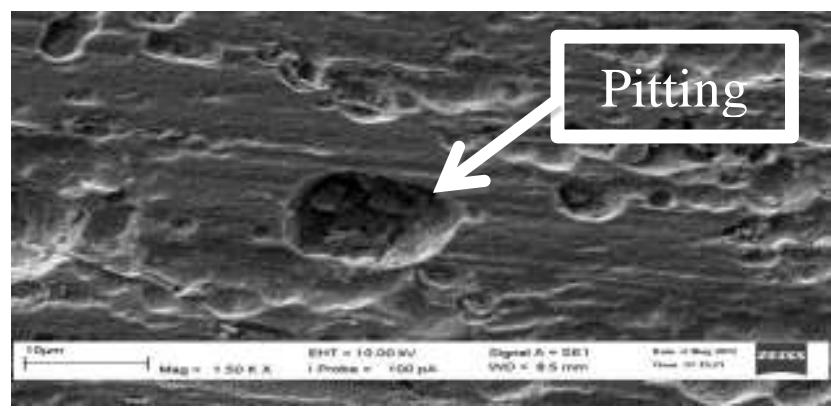

Figure 10. Corrosion defect after electrochemical test.

\section{CONCLUSIONS}

In this paper, an attempt was made to determine the effects of combined welding voltage, filler material and the heat-treatment process on the corrosion behavior of AISI 1010 carbon steel. The butt joint specimens were performed based on three different welding voltages, two types of filler materials and under a full annealing process. In this research, welding voltage has a direct influence on the welding heat input, which in turn has a significant effect on the corrosion rate of welded AISI 1010 carbon steel. Based on the findings, it is summarized that the corrosion rate is minimum when a welding voltage of $V=21 \mathrm{~V}$, ER 308L filler material and a full annealing process are used for the welding of AISI 1010 carbon steel.

\section{ACKNOWLEDGEMENTS}

The authors are obliged to Universiti Malaysia Pahang for providing laboratory facilities and financial assistance under the final year project scheme.

\section{REFERENCES}

[1] Fontana MG. Corrosion Engineering. 3rd ed. singapore: mcgrow hill; 1986.

[2] Kadhim FS. Investigation of Carbon Steel Corrosion in Water Base Drilling Mud. Modern Applied Science. 2011;5:224-9.

[3] Haque MM, Limon SA, Moniruzzaman M, Bepari MMA. Corrosion comparison of galvanized steel and aluminum in aqueous environments. International Journal of Automotive and Mechanical Engineering. 2014;9:1758-67.

[4] Ridha M, Fonna S, Huzni S, Supardi J, Ariffin AK. Atmospheric corrosion of structural steels exposed in the 2004 tsunami-affected areas of Aceh. 
International Journal of Automotive and Mechanical Engineering. 2013;7:101422.

[5] Funderburk RS. Key concepts in welding engineering. Welding Innovation. $1999 ; 16$.

[6] Charde N. Characterization of spot weld growth on dissimilar joints with different thicknesses. Journal of Mechanical Engineering and Sciences. 2012;2:172-80.

[7] Davis JR. Basic understanding of weld corrosion, corrosion of weldments. New York: ASM International; 2006.

[8] Fushimi K, Naganuma A, Azumi K, Kawahara Y. Current distribution during galvanic corrosion of carbin steel welded with Type-309 stainless steel in $\mathrm{NaCl}$ solution. Corrosion Science. 2008;50:903-11.

[9] Uhlig HH. Corrosion and Corrosion Control. New York: John Wiley \& Sons Inc.; 1963.

[10] Charde N. Effects of electrode deformation of resistance spot welding on 304 austenitic stainless steel weld geometry. Journal of Mechanical Engineering and Sciences. 2012;3:261-70.

[11] Ishak M, Shah LH, Aisha ISR, Hafizi W, Islam MR. Study of resistance spot welding between aisi 301 stainless steel and AISI 1020 carbon steel dissimilar alloys. Journal of Mechanical Engineering and Sciences. 2014;6:793-806.

[12] Nuraini AA, Zainal AS, Azmah Hanim MA. The effects of welding parameters on butt joints using robotic gas metal arc welding. Journal of Mechanical Engineering and Sciences. 2014;6:988-94.

[13] Gooch TG. Stress corrosion cracking of welded joints in high strength steels weld. Welding. 1974;53:2877-982.

[14] Charde N. Microstructure and fatigue properties of dissimilar spot welds joints of AISI 304 and AISI 1008. International Journal of Automotive and Mechanical Engineering. 2013;7:882-99.

[15] Shah LH, Akhtar Z, Ishak M. Investigation of aluminum-stainless steel dissimilar weld quality using different filler metals. International Journal of Automotive and Mechanical Engineering. 2013;8:1121-31.

[16] Rajakumar S, Muralidhara C, Balasubramanian V. Predicting tensile strenght, hardness and corrosion rate friction stir welded AA6061-T6 aluminium alloy Joints. Materials and Design. 2011;32:2878-90.

[17] Yousefieh M, Shamanian M, Saatchi A. Optimization of the Pulsed Current Gas Tungsten Arc Welding (PCGTAW) Parameters for corrosion resistance of super duplex stainless steel (UNS S32760) welds using Taguchi method. Alloys and Compounds. 2011;509:782-8.

[18] Fahimpour V, Sadrnezhaad SK, Karimzadeh F. Corrosion behaviour of AL 6061 alloy joined by friction stir welding and gas tungsten arc welding methods. Materials and Design. 2012;39:329-33.

[19] Manning R, Ewing, J. (2009). .RACQ Vehicles Technologies. Temperatures in cars survey. RACQ Vehicles Technologies. 2009:1-21.

[20] Silva CC, Miranda HC, Sant'Ana H, Farias JP. Predticting tensile hardness and petroleum corrosion evaluation of 316L/AWS E309 Mol-16 weld metal. Materials Characterization. 2008;60:2878-90.

[21] Udomphol T. Solidification and phase transformations in welding. 2007. 
[22] Kumaresh SP. Influence of heat input on high temperature weldment corrosion in submerged arc welded power plant carbon steel. Materialas and Design. 2007;29:1036-42.

[23] Iversen A, Leffler B. 3.04 - Aqueous corrosion of stainless steels. In: Stott BCGLLRS, editor. Shreir's Corrosion. Oxford: Elsevier; 2010. p. 1802-78.

[24] Garner A. The effect of autogeneous welding on chloride pitting corrosion in austenitic stainless steels. Corrosion 1979;35:108-14.

[25] Noor EA, Al-Moubaraki AH. Corrosion behavior of mild steel in hydrochloric acid solutions. International Journal Electrochemical Science. 2008;3:806-18. 